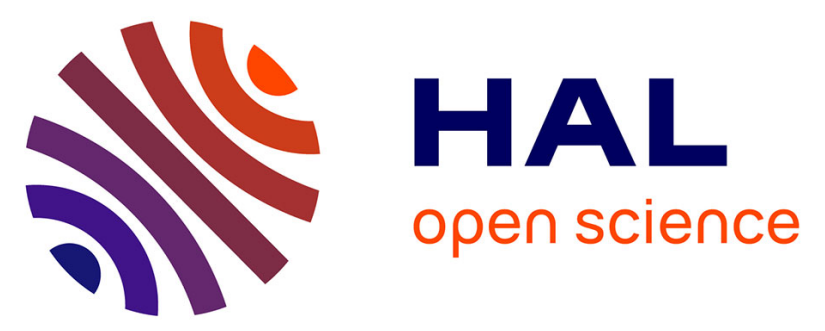

\title{
Membrane Fluidity as a New Means to Selectively Target Cancer Cells with Fusogenic Lipid Carriers
}

Julien Bompard, Annalisa Rosso, Leyre Brizuela, Saïda Mebarek, Loïc Blum, Ana-Maria Trunfio-Sfarghiu, Giovanna Lollo, Thierry Granjon, Agnès Girard-Egrot, Ofelia Maniti

\section{To cite this version:}

Julien Bompard, Annalisa Rosso, Leyre Brizuela, Saïda Mebarek, Loïc Blum, et al.. Membrane Fluidity as a New Means to Selectively Target Cancer Cells with Fusogenic Lipid Carriers. Langmuir, 2020, 36 (19), pp.5134-5144. 10.1021/acs.langmuir.0c00262 . hal-03083631

\section{HAL Id: hal-03083631 \\ https://hal.science/hal-03083631}

Submitted on 23 Dec 2020

HAL is a multi-disciplinary open access archive for the deposit and dissemination of scientific research documents, whether they are published or not. The documents may come from teaching and research institutions in France or abroad, or from public or private research centers.
L'archive ouverte pluridisciplinaire HAL, est destinée au dépôt et à la diffusion de documents scientifiques de niveau recherche, publiés ou non, émanant des établissements d'enseignement et de recherche français ou étrangers, des laboratoires publics ou privés. 


\section{SUPPORTING INFORMATION}

\section{Membrane Fluidity as a New Mean to Selectively Target Cancer Cells with Fusogenic Lipid Carriers}

Julien Bompard ${ }^{1}$, Annalisa Rosso², Leyre Brizuela ${ }^{1}$, Saïda Mebarek' ${ }^{1}$ Lö̈c J. Blum ${ }^{1}$, AnaMaria Trunfio-Sfarghiu ${ }^{3}$, Giovanna Lollo ${ }^{2}$, Thierry Granjon ${ }^{1}$, Agnès Girard-Egrot ${ }^{1}$, Ofelia Maniti $^{1 *}$

1: Institut de Chimie et Biochimie Moléculaires et Supramoléculaires, ICBMS UMR 5246, Univ Lyon, Université Lyon 1, CNRS, Lyon, France

2: Laboratoire d'Automatique, de Génie des Procédés et de Génie Pharmaceutique, LAGEPP UMR 5007, Univ Lyon, Université Lyon 1, CNRS, Lyon, France

3: Laboratoire de Mécanique des Contacts et Structures, LaMCoS UMR 5259, Univ Lyon, Université Lyon 1, CNRS, Lyon, France

*corresponding author : ofelia.maniti@univ-lyon1.fr

Number of pages: 7

Number of figures: 6

Number of tables: 0 


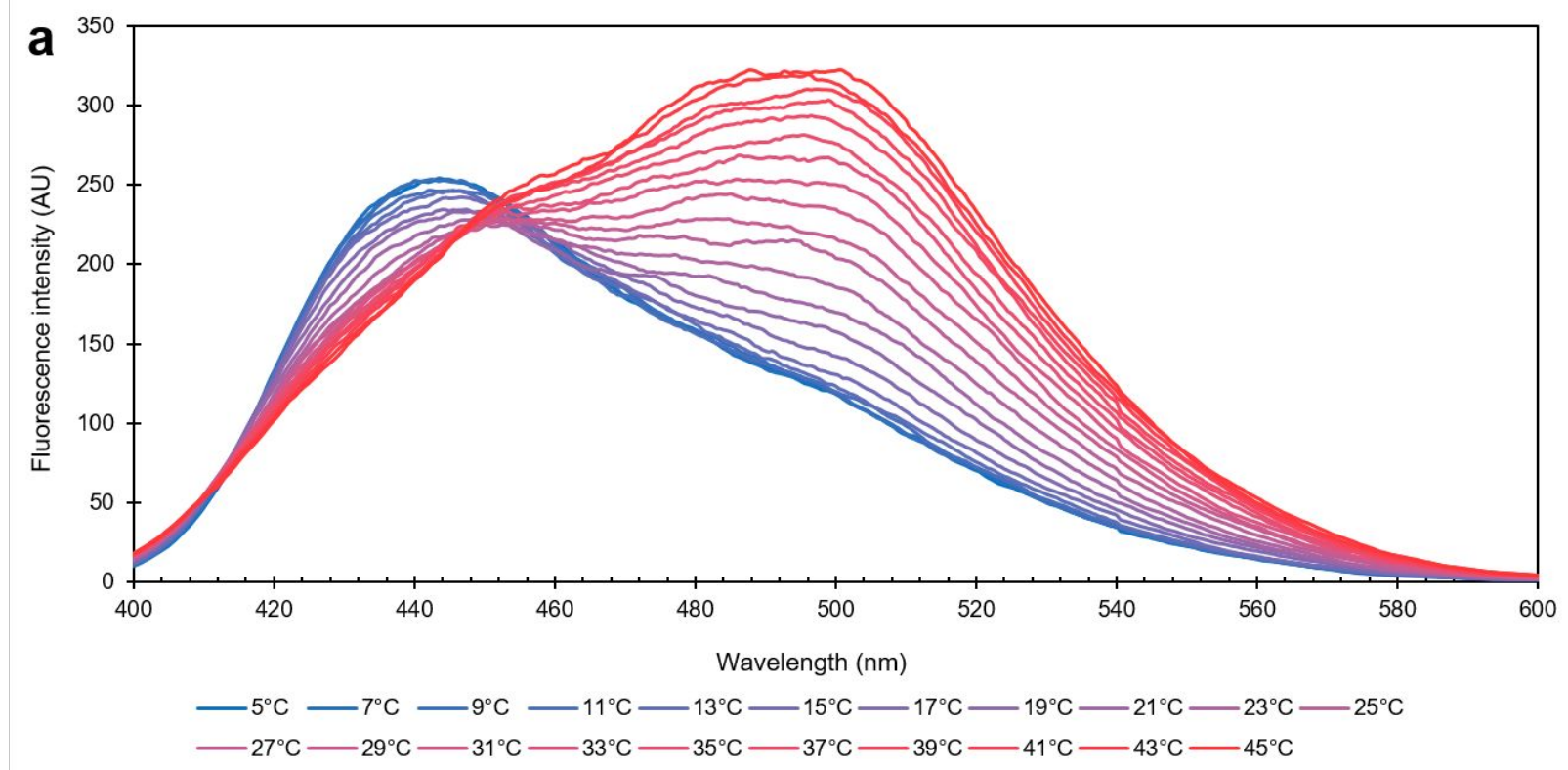

b

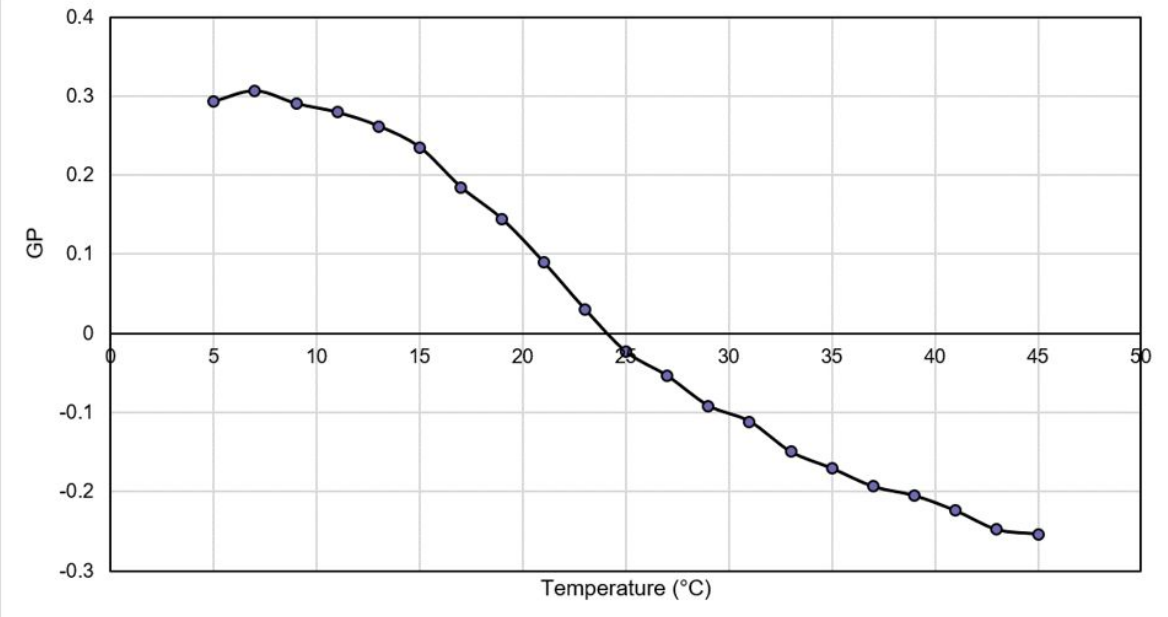

Figure S1. Dioll accurately reports the membrane fluidity state of liposome membranes.

a) Fluorescence spectra of DMPC liposomes incubated with Dioll for $15 \mathrm{~min}$, from $5^{\circ} \mathrm{C}$ to $45^{\circ} \mathrm{C}$.

b) GP measurements, showing an inflexion at $24^{\circ} \mathrm{C}$, the usual phase-transition temperature of DMPC. 


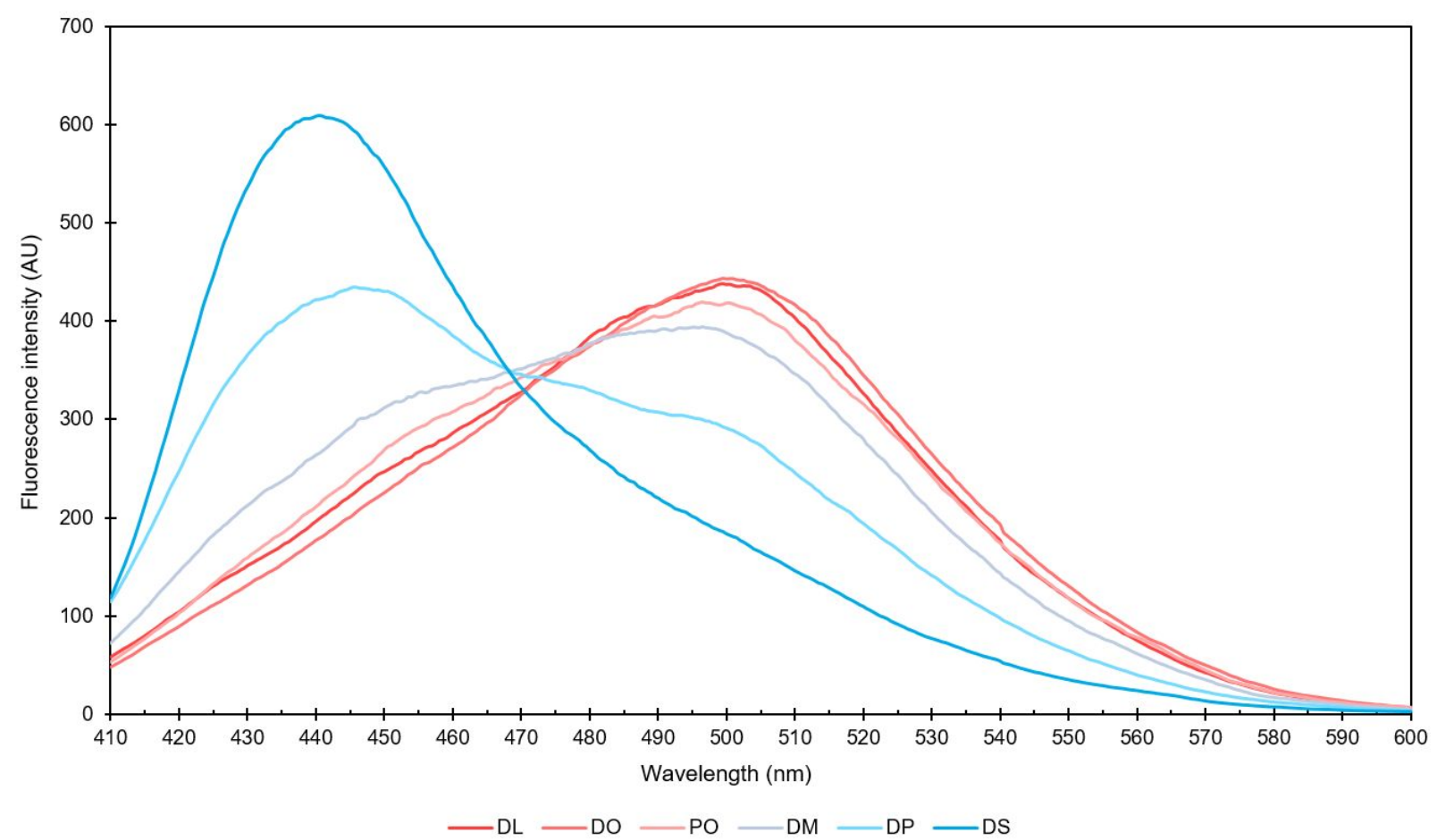

Figure S2. Dioll fluorescence spectra in liposomes with varying phase-transition temperatures reports differences in membrane fluidity states of liposomes made of $80 \%$ PC and $20 \%$ DOPE. 


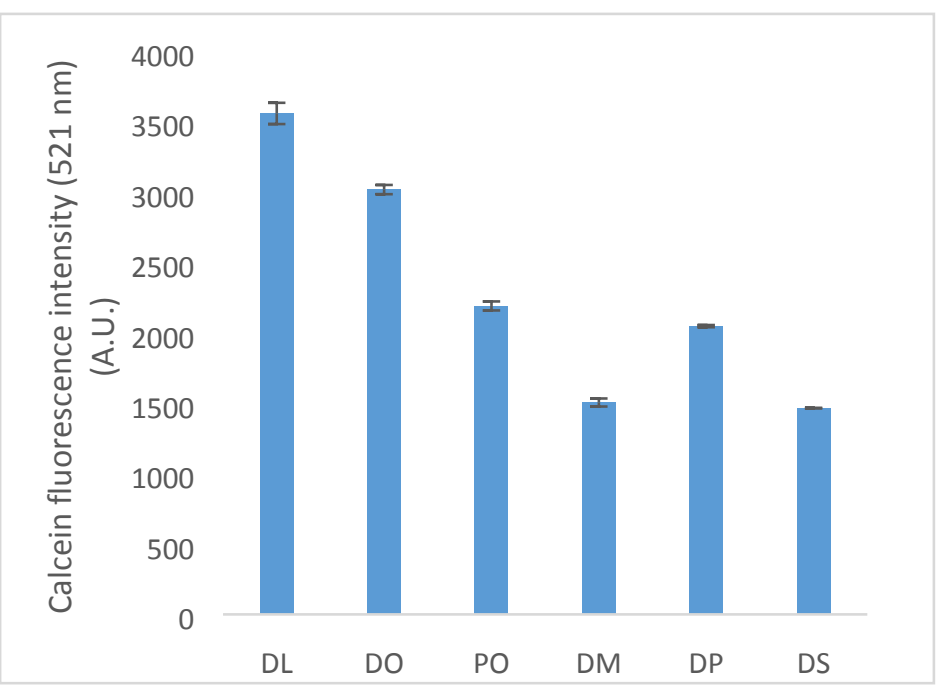

Figure S3. Calcein load in liposomes. Calcein fluorescence intensity at $521 \mathrm{~nm}(488 \mathrm{~nm}$ excitation) as a function of liposome preparation for a liposome concentration of $100 \mu \mathrm{g} / \mathrm{ml}$. Calcein was loaded in the liposomes at a concetration of $5 \mu \mathrm{M}$. Free calcein was removed with size exclusion chromatography. 

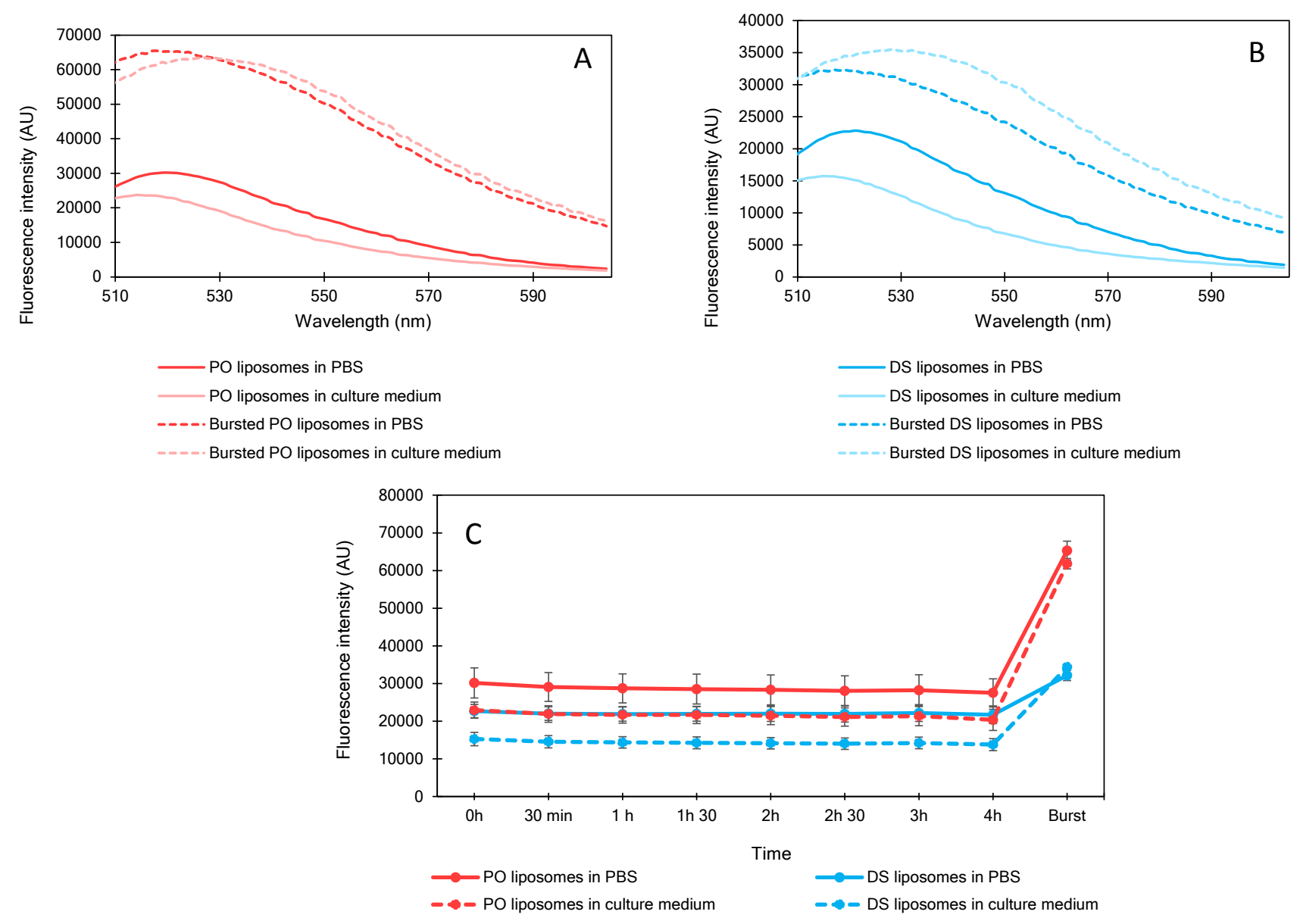

Figure S4: Liposome stability in cell culture medium. PO (A) and DS (B) liposomes were loaded with $60 \mathrm{mM}$ calcein and diluted either in PBS or in FBS-containing DMEM medium. Fluorescence spectra were recorded after excitation at $488 \mathrm{~nm}$ before (full lines) and after (dotted lines) liposome bust with $10 \mu \mathrm{HCl} 1 \mathrm{M}$. The fluorescence intensity increased after liposome burst indicated release from quenching. C. Evolution of calcein fluorescence (measured at maximum emission wavelenght, $521 \mathrm{~nm}$ ) with time in PBS (full lines) or in FBS $10 \%$ cell culture medium. Fluorescence was low and constant for several hours, both in PBS and in cell culture medium, but drastically increased after liposome burst indicating that FBScontaining media did not affect liposome integrity. 
DA liposomes / WPMY-1 cells
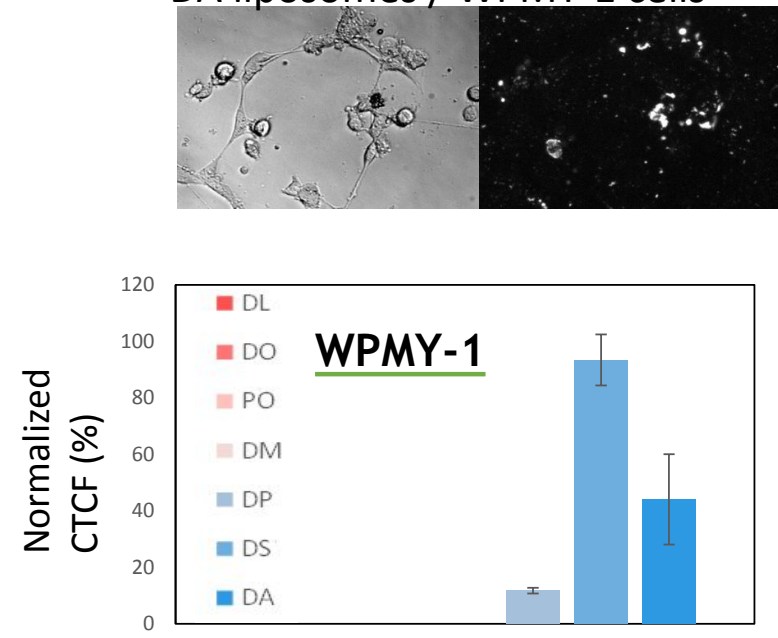

DA liposomes / PC-3 cells
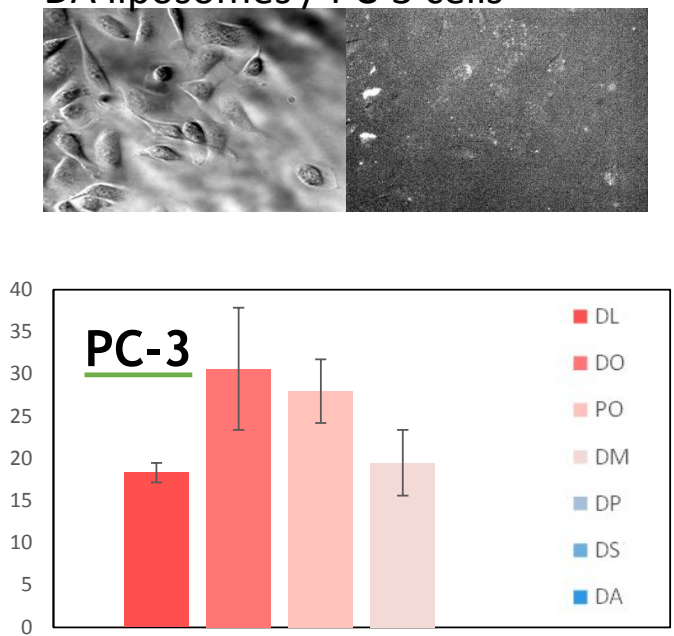

Figure S5: DA liposomes (composed of $78 \%$ of DAPC (C20:0), $20 \%$ DOPE and $2 \%$ NBD-PE) interact with WPMY-1 but not PC-3 cells. Top: fluorescence microscopy images of WPMY-1 (left) or PC-3 cells incubated with DA liposomes. Bottom: Fluorescence intensity (CTCF) quantified on fluorescence images and normalized over the maximum fluorescence intensity value. Left: WPMY-1, right: PC-3 cells incubated with DL, DO, PO, DM, DP, DS and DA liposomes. 

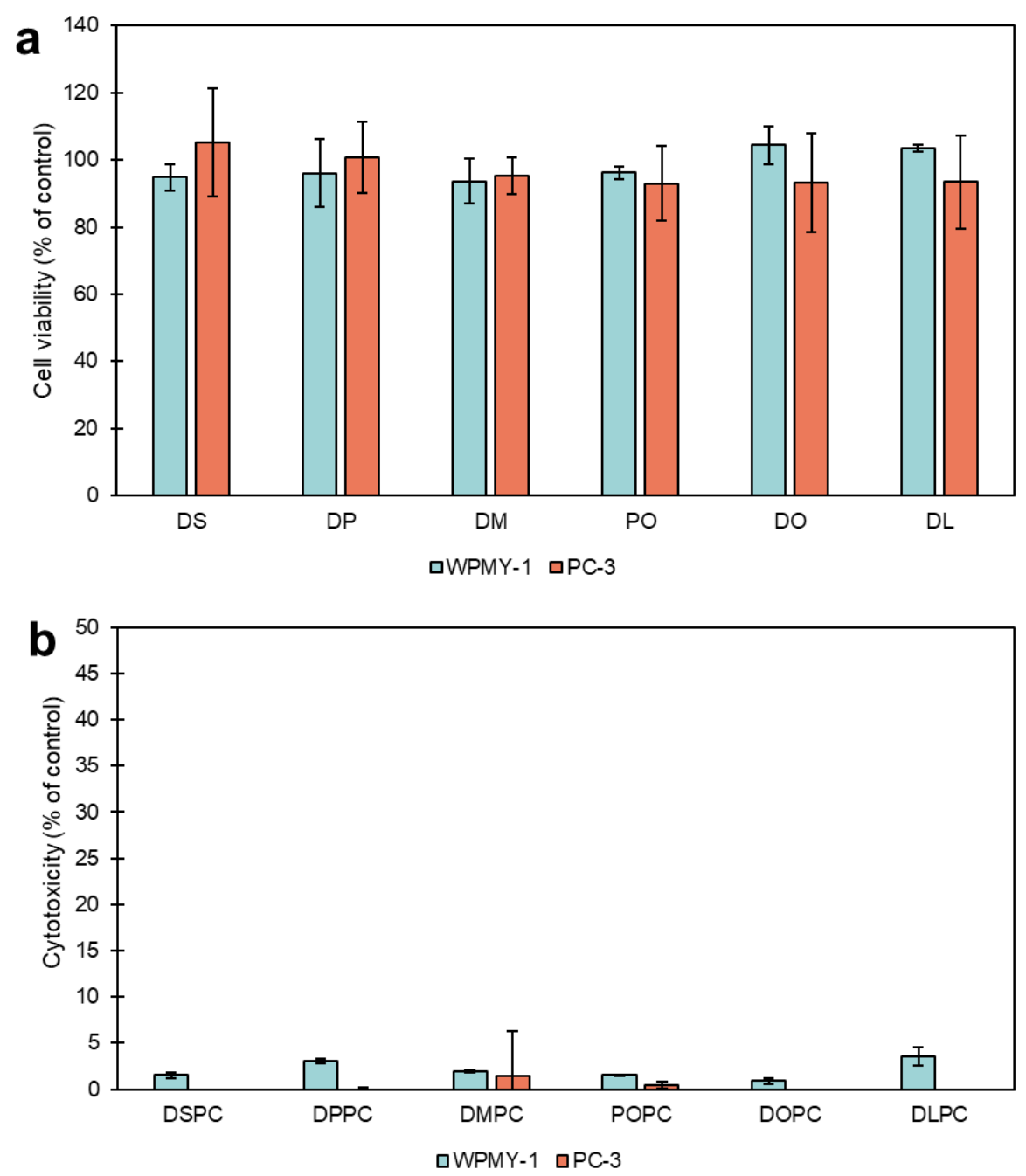

Figure S6. Liposomes do not affect cell viability and show no cytotoxic effect. a) Cell viability quantification, assessed on plated cells with the MTT assay $2 \mathrm{~h} 30$ after liposome treatment. Results expressed as a percentage of cell viability relative to an untreated control corresponding to $100 \%$ viability. b) Cytotoxicity quantification, assessed on the same cells than (a) with the LDH assay. Results expressed as a percentage of cell death relative to an untreated control corresponding to $0 \%$ toxicity and a control treated with $10 \%$ Triton $\mathrm{X}-100$ corresponding to $100 \%$ toxicity. 